\title{
Erratum to: Seismic interpretation of the Aptian Alamein Dolomite in the Razzak oil field, Western Desert, Egypt
}

\author{
Mohamed Abdel-Fattah • Maged Gameel • Samir Awad • \\ Ali Ismail
}

Published online: 14 November 2014

(C) Saudi Society for Geosciences 2014

Erratum to: Arab J Geosci

DOI 10.1007/s12517-014-1595-4

Regrettably, the online version of this article contained an error. The family name of one of the authors was incorrect. Ali Ismaila should be spelled as Ali Ismail. The name is now correctly presented in this article. In addition, Dr. Ismail's corrected affiliation is given below.

The online version of the original article can be found at: http://dx.doi.org/10. 1007/s12517-014-1595-4.

M. Abdel-Fattah $(\triangle)$

Geology Department, Faculty of Science, Suez Canal University,

Ismailia, Egypt

e-mail: mabdelfattah99@gmail.com

\section{Gameel}

Burg El-Arab Petroleum Company, Cairo, Egypt

S. Awad

Geology Department, Faculty of Science, Ain Shams University,

Cairo, Egypt

\section{A. Ismail}

Geological Sciences Department, National Research Centre, Dokki,

Cairo, Egypt 